11. Попов С.Ю. Иллюстрированный полевой ключ для определения наиболее распространенных листостебельных мхов лесной зоны центральной России. M., 2008. $41 \mathrm{c}$.

12. Мельничук В.М. Определитель лиственных мхов средней полосы и юга Европейской части СССР. К.: Наукова думка, 1970. 444 с.

13. Лукашин Ю.П. Адаптивные методы краткосрочного прогнозирования временных рядов. М.: Финансы и статистика, 2003. 416 с.

14. Штина Э.А. Альгофлора старых промышленных отвалов Урала и ее роль в биологической рекультивации // Растения и промышленная среда. Свердловск, 1989. С. 56-66.

15. Кабиров Р.Р., Пурина Е.С., Сафиуллина Л.М. Почвенные водоросли: качественный состав, количественные характеристики, использование при проведении экологического мониторинга // Успехи современного естествознания. 2008. № 5. С. 38-39.

16. Кабиров Р.Р. Роль почвенных водорослей в антропогенных экосистемах // Успехи современного естествознания. 2007. № 6. С. 12-15.
17. Панкратова Е.М., Домрачева Г.И., П Перлинова Г.И. Экспресс-метод определения биологического благополучия почв на базе фототрофных микроорганизмов // Рациональное использование земельных ресурсов России. Киров, 1993. С. 122-123.

18. Кузяхметов Г.Г. Водоросли зональных почв степи и лесостепи // Почвоведение. 1991. № 9. С. 63-71.

19. Стифеев А.И. Рекультивация земель и почвообразование в техногенных ландшафтах КМА: дис. ... д-ра с/х. наук. Курск, 1993.

20. Игнатов М.С., Игнатова Е.А. Флора мхов средней части Европейской России. М., 2003. Т. 1. 608 с.

21. Коршиков И.И., Михеенко И.П., Тарабрин В.П. Перспективы использования мхов в рекультивации отвалов угольных шахт Донбасса // Проблемы рекультивации нарушенных земель: тезисы докладов V Уральского совещания. Свердловск, 1988. С. 117-118.

22. Бойко М.Ф. Мохообразные начальных стадий первичных сукцессий на субстратах антропогенного происхождения // Экология. 1991. № 2. С. 21-26.

23. Игнатов М.С., Игнатова Е.А. Флора мхов средней части Европейской России. М., 2011. Т. 1.608 с.

\title{
SOIL ALGAE AND MOSSES ROLE IN BIOCENOSES FORMATION IN THE TAILINGS OF MIKHAILOVSKY MINING AND BENEFICIATION PLANT OF KURSK MAGNETIC ANOMALY
}

(C) 2018

Nagornaya Olga Vyacheslavovna, candidate of biological sciences, associate professor of Ecology, Horticulture and Plant Protection Department Kursk State Agricultural I.I. Ivanov Academy (Kursk, Russian Federation)

Golovastikova Antonina Valentinovna, candidate of agricultural sciences, associate professor of Merchandising Disciplines Department

Kursk Institute of Cooperation (branch) of Belgorod University of Cooperation, Economics and Law

(Kursk, Russian Federation)

Abstract. The paper presents the results of studies investigating the role of representatives of Algae and Bryophyta divisions in the composition of biocenoses dumps loess-like loam and clay of the Callovian of different ages (5-, 15-, 25 years) of Mikhailovsky Mining and Beneficiation Plant of Kursk Magnetic Anomaly. The author considers the role of soil Algae and mosses as indicators of biocenosis changes in connection with the peculiarities of the lithological framework and age of the dumps. It is proved that successione changes in communities of soil Algae and mosses coincide with succesional changes in the phytocenoses of the dumps in General. Studies have shown that the primary satelitales dumps are the representatives of the department of blue-green Algae Cyanophyta. They form a mono community in 5 year dumps clay of the Callovian and dominate in 5 year dumps. Further formation of the algae Alps in all types of studied rocks is of zonal type. The first of the mossy plants of the Bryophyta dumps division inhabits Ceratodon purpureus (Hedw.). It is the dominant species and persists on all breeds up to the age of 25 as the least demanding of the substrate. Further, the formation of the community of mosses is on a zonal type and lesavignon loam, on average, 15 years faster. It is found that algal communities and bryophytes cenoses form at different speeds on the soil stockpiles. It has been calculated that the stabilization of Algae cenoses will require about 19 years for the Quaternary loess and 32 years on the clay of the Callovian. Stabilization of the community of moss will require about 35 years for the loess and about 70 years on the clay of the Callovian.

Keywords: KMA; Kursk Magnetic Anomaly; Mikhailovsky GOK; Kursk Region; Algae; Bryophyta; dumps of overburden; soils; loess-like loam; clay Callovian; syngenetic succession; cenoses; mossy plants; soil Algae; antenna properties; zonal soil.

УДК 581.9

Статья поступила в редакцию 01.11.2017

\section{ЭКОЛОГО-БОТАНИЧЕСКИЕ ОСОБЕННОСТИ ФЛОРЫ ЖЕЛЕЗНОДОРОЖНЫХ МАГИСТРАЛЕЙ СРЕДНЕГО ПОВОЛЖЬЯ}

(C) 2018

Никитин Николай Александрович, аспирант кафедры биологии, экологии и методики обучения Самарский государственный соииально-педагогический университет (2. Самара, Российская Федераиия)

Аннотация. Работа подводит итог исследований экологических особенностей флоры полосы отвода железных дорог Среднего Поволжья. Установлено отсутствие, в большинстве случаев, значимых различий между аборигенными и чужеродными видами в сложении флоры железных дорог, а также заселении ими 
функциональных зон. Наиболее значимые различия зафиксированы между аборигенными и чужеродными видами в сложении семейств, что, в свою очередь, не оказывает решающего значения в сложении ими флоры в целом. С уверенностью можно говорить о большей значимости экологических особенностей территории произрастания особей, чем о биологических особенностях видов и семейств при формировании флоры железных дорог. Разработанная «шкала угнетения» позволила в полевых условиях оперативно определять характеристики той или иной особи, что значительно повысило эффективность составления первичного конспекта флоры. В ходе проведенных исследований была установлена зависимость между степенью угнетения растительных организмов и расстоянием до железнодорожного полотна. Также установлено отсутствие значимых различий между реактогенностью аборигенных и чужеродных видов на активное антропогенное воздействие в пределах полосы отвода железных дорог - обе группы проявляют сходные тенденции угнетения.

Ключевые слова: флора железных дорог; экологические условия; антропогенное воздействие; железнодорожный транспорт; угнетение жизнедеятельности особей; таксономическая структура флоры; антропогеннонарушенные территории; трансформация флоры; чужеродные виды; аборигенные виды.

\section{Введение}

Изучение влияния железнодорожных магистралей на фитоценозы - одна из актуальных проблем современной экологии и ботаники. Исследование процессов, происходящих на территориях, прилегающих к железнодорожному полотну, важно с точки зрения понимания влияния, которое оказывает инфраструктура железнодорожного транспорта как на особи растительных организмов, так и на формирующуюся вдоль следования железных дорог флору.

В работах современных исследователей значительное внимание уделяется флористическим характеристикам территорий, проведен всесторонний анализ состава флоры, ареалов происхождения видов, их жизненных форм и других характеристик [1-4].

Исследователи указывают на формирование под действием железных дорог некоей общности видов, не объединяемой во флору, но сохраняющей характерные свойства именно в пределах территории, прилегающей к железнодорожному полотну. В отечественном научном дискурсе Д.И. Литвинов ввел понятие «железнодорожные растения» - расселяющиеся вдоль следования железнодорожных магистралей и станций, при этом не распространяющиеся в другие места [5]. В европейской, в частности немецкой, научной литературе встречаются определения «eisanbahntypisch» и «Eisenbahnwanderer» [6], в целом семантически соответствующие «железнодорожным растениям» Литвинова.

Согласно большинству современных работ железнодорожные магистрали - это коридоры активного проникновения на определенные территории чужеродных видов [1-5; 7-9].

Другой гипотезой, формулируемой исследователями, является большая активность чужеродных видов растений, в большинстве своем сорных, в расселении по рудеральным местам обитания вдоль следования железных дорог [2; 3; 5-8; 10]. Также указывается, что некоторые семейства, согласно своим биологическим особенностям, более активны в заселении рудеральных мест обитания, в то время как другие проявляют антропофобные свойства $[1 ; 11]$.

На сегодняшний момент заметна явная нехватка экологических исследований железнодорожных магистралей, сопряженных с ботаническими исследованиями, с целью выявления степени влияния железнодорожной инфраструктуры на особи растительных организмов. Также важно исследование состава и структуры флоры не в целом, а исходя из экологического зонирования прилегающей территории, формирующей все уровни структурных особенностей флористических комплексов (вид - род - семейство - флора).

Проведение экологических и ботанических исследований флоры железнодорожных магистралей важно и актуально, так как позволит установить роль экологических условий и основных тенденций и факторов, влияющих на формирование флоры, прогнозировать возможные проникновения и расселения карантинных сорняков и инвазионных видов на новые территории, планировать защитные мероприятия для предотвращения или контроля этих процессов.

Целью проведенных исследований является эколого-ботаническое обследование железнодорожных магистралей и проверка гипотезы о первичности экологических условий произрастания особей, оказывающих решающее влияние на дифференциацию и формирование флоры железных дорог, и вторичности ботанико-биологических особенностей видов, ее слагающих.

Для достижения поставленной цели решались основные задачи: обследование основных дистанций путей Среднего Поволжья, максимально информативное извлечение выборок и фиксация основных характеристик видов, дальнейшая статистическая обработка с последующей интерпретацией результатов.

\section{Материалы и методы исследований}

В основу исследования легли материалы, собранные автором в 2010-2017 годах. Исследования проводились в Самарской, Ульяновской областях, Республике Татарстан, а также Оренбургской области (не входит в Среднее Поволжье). Обследованные железнодорожные пути являются действующими железнодорожными магистралями, возраст которых варьирует от 30 до 100 лет. Флористические исследования проводились методом линейных трансектов, вдоль следования железнодорожного полотна.

Экологические исследования проводились на пробных площадках площадью 1 м², в переделах которых железнодорожное полотно делилось на функциональные зоны (табл. 1), в зависимости от уровня антропогенной нагрузки.

Выборки извлекались случайным отбором. В одной и той же выборке могут присутствовать одни и те же виды, различающиеся исследуемым признаком.

Выделение функциональных зон продиктовано различиями эксплуатационной нагрузки в зависимости от расстояния до колеи железной дороги.

Для оценки влияния железнодорожного транспорта на растения была разработана «шкала угнетения». Для удобства использования в полевых усло- 
Никитин Н.А.

виях, а также для облегчения дальнейшей обработки все многообразие отклонений было сведено к трем основным степеням (табл. 2). В дальнейшем полученные данные об угнетении и морфометрические показатели особи сравнивались с теоретическими данными, приведенными для конкретного вида [13].

Таблица 1 - Характеристика функциональных зон железнодорожного полотна

\begin{tabular}{|c|c|c|}
\hline $\begin{array}{c}\text { Функ- } \\
\text { цио- } \\
\text { нальная } \\
\text { зона }\end{array}$ & $\begin{array}{l}\text { Характерные } \\
\text { особенности }\end{array}$ & $\begin{array}{c}\text { Примеча- } \\
\text { ния }\end{array}$ \\
\hline $\begin{array}{l}1 \\
\text { (зона } \\
\text { актив- } \\
\text { ной } \\
\text { нагруз- } \\
\text { ки), 0- } \\
2 \text { м }\end{array}$ & $\begin{array}{l}\text { К данной зоне отнесена } \\
\text { территория «от рельса до } \\
\text { рельса». В пределах зоны } \\
\text { антропогенная нагрузка по- } \\
\text { средством железнодорож- } \\
\text { ного транспорта достигает } \\
\text { наивысшей степени. }\end{array}$ & $\begin{array}{l}\text { Для всех } \\
\text { зон имеет } \\
\text { значение } \\
\text { обработка } \\
\text { полотна } \\
\text { гербицида- } \\
\text { ми. }\end{array}$ \\
\hline $\begin{array}{l}2 \\
\text { (зона } \\
\text { опосре- } \\
\text { дован- } \\
\text { ного } \\
\text { воздей- } \\
\text { ствия), } \\
2-4 \text { м }\end{array}$ & $\begin{array}{l}\text { К данной зоне отнесены от- } \\
\text { косы железнодорожной } \\
\text { насыпи. Антропогенное } \\
\text { воздействие посредством } \\
\text { железнодорожного транс- } \\
\text { порта здесь является опо- } \\
\text { средованным через вибра- } \\
\text { ции, передающиеся по суб- } \\
\text { страту, запыленность, шум } \\
\text { и другие. }\end{array}$ & $\begin{array}{l}2 \text { и } 3 \text { зоны } \\
\text { объединены } \\
\text { отсутстви- } \\
\text { ем непо- } \\
\text { средствен- } \\
\text { ного воз- } \\
\text { действия } \\
\text { подвижного } \\
\text { состава. } \\
\text { Для всех } \\
\text { зон харак- }\end{array}$ \\
\hline $\begin{array}{l}3 \\
\text { (зона } \\
\text { слабого } \\
\text { воздей- } \\
\text { ствия), } \\
4-10 \text { м }\end{array}$ & $\begin{array}{l}\text { Включает в себя зону ши- } \\
\text { риной } 4 \text { метра от насыпи. } \\
\text { Данная зона характеризует- } \\
\text { ся особыми «литоральны- } \\
\text { ми» условиями, в которых } \\
\text { железнодорожная насыпь } \\
\text { контактирует с естествен- } \\
\text { ным ландшафтом. }\end{array}$ & $\begin{array}{l}\text { терно нали- } \\
\text { чие искус- } \\
\text { ственного } \\
\text { субстрата, } \\
\text { местами } \\
\text { переме- } \\
\text { шавшегося } \\
\text { с почвой. }\end{array}$ \\
\hline
\end{tabular}

Важно отметить, что при проведении экологических исследований основным объектом исследования была особь и ее характерные особенности, в частности степень угнетения. При обнаружении особей одного вида с различными степенями угнетения обе фиксировались как самостоятельные единицы.

При флористическом и таксономическом анализе и установлении характерных структурных особенностей (родов, семейств, флоры в целом) основными объектами изучения были указанные группы.

Полученные в результате первичной обработки данные анализировались методами математической статистики - при соотнесении выборок по преобладанию какого-либо признака использовался метод углового преобразования Фишера ( явления значимых различий между тремя и более выборками - односторонний дисперсионный анализ Краскела-Уоллиса (Н-критерий), для выявления значимых различий между двумя выборками - критерий Манна-Уитни (U-критерий).
Таблица 2 - Степени угнетения растений в полосе отвода железных дорог

\begin{tabular}{|c|c|c|}
\hline $\begin{array}{c}\text { Степень } \\
\text { угнете- } \\
\text { ния }\end{array}$ & $\begin{array}{c}\text { Характерные особен- } \\
\text { ности растений }\end{array}$ & Примечания \\
\hline $\begin{array}{l}\text { I } \\
\text { (силь- } \\
\text { ное } \\
\text { угнете- } \\
\text { ние) }\end{array}$ & $\begin{array}{l}\text { Отклонения в развитии } \\
\text { габитуса растения за- } \\
\text { трудняет определения } \\
\text { видовой принадлежно- } \\
\text { сти. Не всегда возмож- } \\
\text { на семейственная } \\
\text { идентификация. Зна- } \\
\text { чительные отклонения } \\
\text { в онтогенетическом } \\
\text { развитии (несоответ- } \\
\text { ствие стадии онтогене- } \\
\text { за и времени года тео- } \\
\text { ретическим описани- } \\
\text { ям). Развитие феноти- } \\
\text { пических и морфоло- } \\
\text { гических уродств. По- } \\
\text { гибшие особи. }\end{array}$ & $\begin{array}{l}\text { При сохранно- } \\
\text { сти, фиксируют- } \\
\text { ся также погиб- } \\
\text { шие особи, если } \\
\text { возможна видо- } \\
\text { вая (иногда ро- } \\
\text { довая идентифи- } \\
\text { кация). }\end{array}$ \\
\hline $\begin{array}{l}\text { II } \\
\text { (сред- } \\
\text { нее } \\
\text { угнете- } \\
\text { ние) }\end{array}$ & $\begin{array}{l}\text { Общий вид растения } \\
\text { позволяет без труда } \\
\text { провести видовую } \\
\text { идентификацию. За- } \\
\text { держка онтогенетиче- } \\
\text { ского развития, несо- } \\
\text { ответствие развитию } \\
\text { на определенный веге- } \\
\text { тационный период. }\end{array}$ & \\
\hline $\begin{array}{l}\text { III } \\
\text { (потен- } \\
\text { циаль- } \\
\text { ное } \\
\text { угнете- } \\
\text { ние) }\end{array}$ & $\begin{array}{l}\text { Растения находятся в } \\
\text { зоне воздействия же- } \\
\text { лезнодорожного } \\
\text { транспорта. Незначи- } \\
\text { тельные отклонения в } \\
\text { развитии на данный } \\
\text { вегетационный период. }\end{array}$ & $\begin{array}{l}\text { Растения могут } \\
\text { проявлять следы } \\
\text { отсутствия ви- } \\
\text { димого угнете- } \\
\text { ния, однако пе- } \\
\text { риодическая об- } \\
\text { работка полотна } \\
\text { гербицидами, } \\
\text { вырубка, палы, } \\
\text { техническая ра- } \\
\text { бота, внезапные } \\
\text { выбросы загряз- } \\
\text { няющих веществ } \\
\text { могут серьезным } \\
\text { образом сказать- } \\
\text { ся на растениях. }\end{array}$ \\
\hline
\end{tabular}

\section{Результаты исследований и их обсуждение}

За время исследования на железных дорогах зарегистрировано произрастание 330 видов сосудистых растений, 145 видов являются чужеродными (табл. 3 , 4) общим количеством 502 особи.

Таблица 3 - Распределение фракций флоры по функциональным зонам полотна (по результатам первичной обработки выборок)

\begin{tabular}{|c|c|c|c|}
\hline $\begin{array}{c}\text { Функци- } \\
\text { ональная } \\
\text { зона }\end{array}$ & $\begin{array}{c}\text { Количество } \\
\text { особей або- } \\
\text { ригенных ви- } \\
\text { дов, шт. }\end{array}$ & $\begin{array}{c}\text { Количество } \\
\text { особей чу- } \\
\text { жеродных } \\
\text { видов, шт. }\end{array}$ & $\begin{array}{c}\text { Общее ко- } \\
\text { личество } \\
\text { особей, шт. }\end{array}$ \\
\hline 1 & 23 & 27 & 50 \\
\hline 2 & 117 & 102 & 219 \\
\hline 3 & 128 & 105 & 233 \\
\hline$\sum$ & 268 & 233 & 502 \\
\hline
\end{tabular}


Никитин Н.А

Эколого-ботанические особенности флоры железнодорожных магистралей..

03.02.00 - общая биология

Таблица 4 - Распределение особей растений и степени их угнетения по функциональным зонам железнодорожного полотна (по результатам первичной обработки выборок)

\begin{tabular}{|c|c|c|c|c|c|c|}
\hline $\begin{array}{c}\text { Функ- } \\
\text { цио- } \\
\text { нальная }\end{array}$ & $\begin{array}{c}\text { Особи аборигенных } \\
\text { видов по степени } \\
\text { угнетения, шт. }\end{array}$ & \multicolumn{2}{c|}{$\begin{array}{c}\text { Особи чужеродных } \\
\text { видов по степени } \\
\text { угнетения, шт. }\end{array}$} \\
\cline { 2 - 7 } & I & II & III & I & II & III \\
\hline 1 & 7 & 11 & 5 & 10 & 15 & 2 \\
\hline 2 & 1 & 12 & 105 & 1 & 17 & 84 \\
\hline 3 & 1 & 27 & 100 & 1 & 30 & 75 \\
\hline \multirow{2}{*}{$\sum$} & 9 & 50 & 210 & 12 & 62 & 159 \\
\cline { 2 - 7 } & \multicolumn{3}{|c|}{268} & \multicolumn{4}{|c}{233} \\
\hline
\end{tabular}

Соотнесение функциональных зон по степени угнетения жизнедеятельности растений преследует цель установления значимых различий в количестве тех или иных степеней угнетения между выборками (зонами).

Поскольку в сравнении используются три выборки со значениями больше 50 каждая, для установления статистически значимых различий между ними использовался односторонний дисперсионный анализ Каскела-Уоллиса (Н-критерий). Данные, полученные в ходе вычислений, подтвердили значимость различий между выборками по данному показателю $\left(\mathrm{H}_{\text {эмп. }}=95,65494, \mathrm{p}=1,82207930079 \mathrm{e}+18\right.$ при $\left.\mathrm{p} \leq 0,01\right)$. Для попарного сравнения выборок применялся метод углового преобразования Фишера (метод $\varphi$ ), с целью установления различий в большую или меньшую стороны. Результаты приведены в таблице 5.

Таблица 5 - Сравнение функциональных зон железнодорожного полотна по степени угнетения растений (по критерию углового преобразования Фишера)

\begin{tabular}{|c|c|c|c|}
\hline $\begin{array}{c}\text { Сравни- } \\
\text { ваемые } \\
\text { зоны }\end{array}$ & $\begin{array}{c}\text { Сравниваемый } \\
\text { показатель }\end{array}$ & $\begin{array}{c}\text { Значе- } \\
\text { ние } \\
\varphi_{\text {эм. }}\end{array}$ & $\begin{array}{c}\text { Значе- } \\
\text { ние } \\
\mathrm{p}\end{array}$ \\
\hline $1-2$ & I степень угнетения & $\mathbf{6 , 7 2 8}$ & $\mathbf{0 , 0}$ \\
\hline $1-3$ & І степень угнетения & $\mathbf{7 , 1 5 2}$ & $\mathbf{0 , 0}$ \\
\hline $2-3$ & I степень угнетения & $\mathbf{0 , 6 4}$ & $\mathbf{0 , 2 6 0 9}$ \\
\hline $1-2$ & II степень угнетения & $\mathbf{5 , 9 6 6}$ & $\mathbf{0 , 0}$ \\
\hline $1-3$ & II степень угнетения & $\mathbf{4 , 1 6 5}$ & $\mathbf{0 , 0}$ \\
\hline $2-3$ & II степень угнетения & $\mathbf{3 , 3 3}$ & $\mathbf{0 , 0 0 0 4}$ \\
\hline $1-2$ & III степень угнетения & $\mathbf{6 , 2 9 8}$ & $\mathbf{0 , 0}$ \\
\hline $1-3$ & III степень угнетения & $\mathbf{8 , 0 5 4}$ & $\mathbf{0 , 0}$ \\
\hline $2-3$ & III степень угнетения & $\mathbf{2 , 8 5 6}$ & $\mathbf{0 , 0 0 2 1}$ \\
\hline
\end{tabular}

Примечание. $\mathrm{p} \leq 0,01 ; \quad(\varphi \leq 1,64 \quad(\mathrm{p} \leq 0,05) \quad$ и $\varphi \leq 2,31$ ( $\mathrm{p} \leq 0,01)$ Если $\varphi_{\text {эмп }}>\varphi$ кр., $\mathrm{H}_{0}$ отвергается). Жирным шрифтом выделены статистически значимые результаты.

Соотнесение функциональных зон железнодорожного полотна между собой по степени угнетения растений во всех случаях показало статистически значимые различия.

I степень угнетения преобладает в 1 зоне, в то время как во 2 и 3 различия находятся на границе достоверности. II степень угнетения преобладает во 2 и 3 зонах, что близко по значению III степени угнетения в этих зонах. Полученные данные позволяют говорить об увеличении степени угнетения растений в непосредственной близости и на откосах железнодорожного полотна.

Анализ распределения особей чужеродных и аборигенных видов в пределах функциональных зон по- казал отсутствие статистически значимых различий между количеством чужеродных и аборигенных особей в пределах 1 и 2 функциональных зон. Значимое различие отмечено в пределах 3 функциональной зоны, где количество особей аборигенных видов преобладает над чужеродными (табл. 6).

Таблица 6 - Сравнение количества особей чужеродных и аборигенных видов внутри функциональных зон железнодорожного полотна (по критерию углового преобразования Фишера)

\begin{tabular}{|c|c|c|c|}
\hline $\begin{array}{c}\text { Функцио- } \\
\text { нальная } \\
\text { зона } \\
\end{array}$ & $\begin{array}{c}\text { Сравниваемые } \\
\text { показатели }\end{array}$ & $\begin{array}{c}\text { Значе- } \\
\text { ние } \\
\varphi_{\text {эмп. }}\end{array}$ & $\begin{array}{c}\text { 3наче- } \\
\text { ние } \\
\mathrm{p}\end{array}$ \\
\hline 1 & $\begin{array}{l}\text { Особи аборигенных/ } \\
\text { чужеродных видов }\end{array}$ & 0,801 & 0,02116 \\
\hline 2 & $\begin{array}{l}\text { Особи аборигенных/ } \\
\text { чужеродных видов }\end{array}$ & 1,527 & 0,0634 \\
\hline 3 & $\begin{array}{l}\text { Особи аборигенных/ } \\
\text { чужеродных видов }\end{array}$ & 2,037 & 0,0208 \\
\hline
\end{tabular}

Примечание. $\mathrm{p} \leq 0,01 ; \quad(\varphi \leq 1,64 \quad(\mathrm{p} \leq 0,05) \quad$ и $\varphi \leq 2,31$ ( $\mathrm{p} \leq 0,01)$. Если $\varphi_{\text {эмп }}>\varphi_{\text {кр. }}, \mathrm{H}_{0}$ отвергается $)$. Жирным шрифтом выделены статистически значимые результаты.

Полученные данные говорят об одинаковой активности и реактогенности аборигенных и чужеродных видов растений на активное воздействие железнодорожного транспорта и его инфраструктуры. Также вероятно, что данный результат стал следствием нивелирования различий между особями различных фракций флоры вследствие того, что в пределах данных зон (1 и 2) антропогенное воздействие имеет наивысшую степень, в то время как в 3 зоне воздействие носит больше опосредованный характер, где в большей степени проявляют влияние прилегающие фитоценозы.

Сравнение функциональных зон между собой по количеству особей аборигенных и чужеродных видов показало отсутствие значимых различий между 1-2 и 1-3 зонами, что вполне соответствует ранее полученным результатам. Появление значимого различия между особями аборигенных и чужеродных видов при переходе от 2 зоны к 3 говорит о схожих тенденциях, как и при внутризональном распределении - возрастающая роль прилегающих фитоценозов и уменьшающееся опосредованное антропогенное воздействие приводят к усилению активности аборигенных видов (табл. 7).

Таблица 7 - Сравнение функциональных зон железнодорожного полотна по количеству особей аборигенных и чужеродных видов растений (по критерию углового преобразования Фишера)

\begin{tabular}{|c|c|c|c|}
\hline $\begin{array}{c}\text { Сравнивае- } \\
\text { мые зоны }\end{array}$ & $\begin{array}{c}\text { Сравниваемые } \\
\text { показатели }\end{array}$ & $\begin{array}{c}\text { Значение } \\
\varphi_{\text {эмп. }}\end{array}$ & $\begin{array}{l}\text { Значе- } \\
\text { ние } p\end{array}$ \\
\hline $1-2$ & $\begin{array}{l}\text { Особи аборигенных/ } \\
\text { чужеродных видов }\end{array}$ & 0,0976 & 0,0164 \\
\hline $1-3$ & $\begin{array}{l}\text { Особи аборигенных/ } \\
\text { чужеродных видов }\end{array}$ & 1,118 & 0,1317 \\
\hline $2-3$ & $\begin{array}{l}\text { Особи аборигенных/ } \\
\text { чужеродных видов }\end{array}$ & 1,778 & $\mathbf{0 , 0 3 7 7}$ \\
\hline
\end{tabular}

Примечание. $\mathrm{p} \leq 0,01 ; \quad(\varphi \leq 1,64(\mathrm{p} \leq 0,05) \quad$ и $\varphi \leq 2,31$ ( $\mathrm{p} \leq 0,01)$ Если $\varphi_{\text {эмп }}>\varphi_{\text {кр. }}, \mathrm{H}_{0}$ отвергается). Жирным шрифтом выделены статистически значимые результаты. 
Таксономический анализ флоры показал, что на долю первых семи семейств приходится $62 \%$ от общего числа зарегистрированных видов (табл. 9). Данного количества достаточно для того, чтобы выявленные тенденции у ведущих семейств экстраполировать в дальнейшем на флору в целом [12].

Видовая и родовая структура ведущих семейств в большинстве случаев обнаруживает значимые разли- чия между чужеродным и аборигенным компонентом, в сторону преобладания аборигенного.

Согласно первичной обработке результатов флористических наблюдений, извлеченные выборки соответствуют зональным характеристикам флоры для средней полосы европейской части Российской Федерации, о чем говорят значения видовой наполняемости семейств (табл. 8, 9, 10) [13].

таблица 8 - Структура ведущих семейств по количеству родов (по результатам первичной обработки данных), а также сопоставление ф-критерием Фишера

\begin{tabular}{|c|l|c|c|c|c|c|}
\hline № & Семейство & $\begin{array}{c}\text { Количество } \\
\text { аборигенных родов }\end{array}$ & $\begin{array}{c}\text { Количество } \\
\text { чужеродных родов }\end{array}$ & $\begin{array}{c}\text { Общее количество } \\
\text { родов }\end{array}$ & $\varphi_{\text {эмп, }}$ & $\mathrm{p}$ \\
\hline 1 & Asteraceae & 25 & 14 & 39 & $\mathbf{2 , 5 2 5}$ & $\mathbf{0 , 0 0 5 8}$ \\
\hline 2 & Poaceae & 19 & 13 & 32 & 1,509 & 0,0557 \\
\hline 3 & Brassicaceae & 7 & 13 & 20 & $\mathbf{1 , 9 2 7}$ & $\mathbf{0 , 0 2 7}$ \\
\hline 4 & Fabaceae & 12 & 3 & 15 & $\mathbf{3 , 5 2 5}$ & $\mathbf{0 , 0 0 0 2}$ \\
\hline 5 & Rosaceae & 5 & 9 & 14 & 1,533 & 0,0626 \\
\hline 6 & Lamiaceae & 6 & 6 & 12 & 0 & 0,5 \\
\hline 7 & Apiaceae & 7 & 2 & 9 & $\mathbf{2 , 4 9 9}$ & $\mathbf{0 , 0 0 6 2}$ \\
\hline & $\sum$ & $\mathbf{8 1}$ & $\mathbf{6 0}$ & $\mathbf{1 4 1}$ & $\mathbf{2 , 5 1}$ & $\mathbf{0 , 0 0 6}$ \\
\hline
\end{tabular}

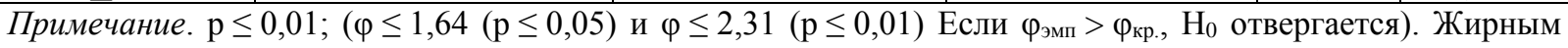
шрифтом выделены статистически значимые результаты.

Таблица 9 - Ведущие семейства флоры железных дорог по количеству видов (по результатам первичной обработки данных), а также результаты сопоставления (-методом Фишера

\begin{tabular}{|c|l|c|c|c|c|c|}
\hline № & Семейство & $\begin{array}{c}\text { Количество } \\
\text { аборигенных видов }\end{array}$ & $\begin{array}{c}\text { Количество } \\
\text { чужеродных видов }\end{array}$ & $\begin{array}{c}\text { Общее количество } \\
\text { видов }\end{array}$ & эмп. & $\mathrm{p}$ \\
\hline 1 & Asteraceae & 48 & 23 & 71 & $\mathbf{4 , 2 8 8}$ & $\mathbf{0 , 0}$ \\
\hline 2 & Poaceae & 25 & 25 & 50 & 0,0 & 0,5 \\
\hline 3 & Brassicaceae & 7 & 16 & 23 & $\mathbf{2 , 7 2 7}$ & $\mathbf{0 , 0 0 3 2}$ \\
\hline 4 & Fabaceae & 17 & 4 & 21 & $\mathbf{4 , 3 2 6}$ & $\mathbf{0 , 0}$ \\
\hline 5 & Rosaceae & 8 & 9 & 17 & 0,343 & 0,3657 \\
\hline 6 & Lamiaceae & 9 & 6 & 15 & 1,103 & 0,135 \\
\hline 7 & Apiaceae & 7 & 2 & 9 & $\mathbf{2 , 4 9 9}$ & $\mathbf{0 , 0 0 6 2}$ \\
\hline \multicolumn{2}{|c|}{$\sum$} & $\mathbf{1 2 1}$ & $\mathbf{8 5}$ & $\mathbf{2 0 6}$ & $\mathbf{3 , 5 6 5}$ & $\mathbf{0 , 0 0 0 2}$ \\
\hline
\end{tabular}

Примечание. $\mathrm{p} \leq 0,01 ;(\varphi \leq 1,64(\mathrm{p} \leq 0,05)$ и $\varphi \leq 2,31$ ( $\mathrm{p} \leq 0,01)$ Если $\varphi_{\text {эмп }}>\varphi_{\text {кр. }}, \mathrm{H}_{0}$ отвергается). Жирным шрифтом выделены статистически значимые результаты.

Различия между количеством родов и видов ведущих семейств флоры, сопоставляемые методом Манна-Уитни, не показали значимых различий (табл. 11). Также значимых различий не показали сравнение выборок по количеству аборигенных и чужеродных видов и аборигенных и чужеродных родов. Полученные данные позволяют говорить о гомогенности выборок по данным показателям и одинаковой наполняемости флоры данными элементами. Выявленные тенденции интерпретируются А.И. Толмачевым [12] как значительные аллохтонные тенденции флоры, находящейся под активным влиянием антропогенного воздействия.

таблица 10 - Ведущие семейства по общему количеству родов и видов

\begin{tabular}{|c|l|c|c|}
\hline № & \multicolumn{1}{|c|}{ Семейство } & $\begin{array}{c}\text { Общее коли- } \\
\text { чество родов }\end{array}$ & $\begin{array}{c}\text { Общее количе- } \\
\text { ство видов }\end{array}$ \\
\hline 1 & Asteraceae & 39 & 71 \\
\hline 2 & Poaceae & 32 & 50 \\
\hline 3 & Brassicaceae & 20 & 23 \\
\hline 4 & Fabaceae & 15 & 21 \\
\hline 5 & Rosaceae & 14 & 17 \\
\hline 6 & Lamiaceae & 12 & 15 \\
\hline 7 & Apiaceae & 9 & 9 \\
\hline & $\sum$ & 141 & 206 \\
\hline
\end{tabular}

Таблица 11 - Соотнесение показателей родовой и видовой наполняемости ведущих семейств по критерию Манна-Уитни

\begin{tabular}{|c|l|c|c|c|}
\hline № & Сравниваемые показатели & $\mathrm{U}_{\text {эмп. }}$ & $\mathrm{U}_{0,01}$ & $\mathrm{U}_{0,05}$ \\
\hline 1 & Кол-во абор. и чуж. родов & 20,5 & 6,0 & 11,0 \\
\hline 2 & Кол-во абор. и чуж. видов & 18,0 & 6,0 & 11,0 \\
\hline 3 & Кол-во видов и родов & 17,0 & 6,0 & 11,0 \\
\hline
\end{tabular}

Таблица 12 - Распределение особей аборигенных и чужеродных видов по функциональным зонам железнодорожного полотна (по результатам первичной обработки выборок)

\begin{tabular}{|c|c|c|c|c|c|c|c|c|}
\hline \multirow{2}{*}{$N d$} & \multirow{2}{*}{ Семейство } & \multicolumn{2}{|c|}{1 зона } & \multicolumn{2}{|c|}{2 зона } & \multicolumn{2}{|c|}{3 зона } & \multirow{2}{*}{$\sum 3$} \\
\hline & & A & Ч & $\mathrm{A}$ & Ч & $\mathrm{A}$ & Ч & \\
\hline 1 & Asteraceae & 10 & 7 & 30 & 27 & 33 & 24 & 131 \\
\hline 2 & Poaceae & 4 & 1 & 21 & 13 & 22 & 17 & 78 \\
\hline 3 & Brassicaceae & 0 & 1 & 8 & 6 & 8 & 9 & 32 \\
\hline 4 & Fabaceae & 1 & 1 & 2 & 1 & 3 & 0 & 8 \\
\hline 5 & Rosaceae & 4 & 4 & 6 & 7 & 3 & 7 & 31 \\
\hline 6 & Lamiaceae & 1 & 1 & 7 & 3 & 5 & 3 & 20 \\
\hline \multirow[t]{3}{*}{7} & Apiaceae & 1 & 1 & 4 & 2 & 5 & 2 & 15 \\
\hline & $\sum_{1}$ & 21 & 16 & 78 & 59 & 79 & 62 & \multirow{2}{*}{$\begin{array}{r}315 \\
\left(\sum 4\right)\end{array}$} \\
\hline & $\sum_{2}$ & \multicolumn{2}{|c|}{37} & \multicolumn{2}{|c|}{137} & \multicolumn{2}{|c|}{141} & \\
\hline
\end{tabular}

Примечание. $A$ - аборигенные виды; $Y$ - чужеродные виды. 
Никитин Н.А.

Эколого-ботанические особенности флоры железнодорожных магистралей..

03.02.00 - общая биология

Таблица 13 - Соотнесение функциональных зон железнодорожного полотна по количеству особей аборигенных и чужеродных видов ведущих семейств, а также общему количеству особей методом Краскела-Уоллиса

\begin{tabular}{|c|l|c|c|}
\hline$№$ & Сравниваемые показатели & $\mathrm{H}_{\text {эмп }}$ & $\mathrm{p}$ \\
\hline 1 & $\begin{array}{l}\text { Кол-во особей абор. видов } \\
\text { в 1, 2, 3 зонах }\end{array}$ & 5,75726 & 0,0561 \\
\hline 2 & $\begin{array}{l}\text { Кол-во особей чуж. видов } \\
\text { в 1, 2, 3 зонах }\end{array}$ & 4,32479 & 0,11505 \\
\hline 3 & $\begin{array}{l}\text { Общее кол-во особей вед. } \\
\text { семейств в 1, 2, 3 зонах }\end{array}$ & 5,94069 & 0,02129 \\
\hline
\end{tabular}

Соотнесение функциональных зон железнодорожного полотна по количеству особей аборигенных и чужеродных видов, а также по общему количеству особей ведущих семейств не показало значимых различий между тремя функциональными зонами (табл. 13). Полученный результат говорит об одинаковой наполняемости зон как аборигенными, так и заносными видами ведущих семейств флоры.

Таблица 14 - Сравнение функциональных зон железнодорожного полотна по распределению особей ведущих семейств ф-методом Фишера

\begin{tabular}{|c|c|c|c|c|}
\hline Сравниваемые зоны & Семейство & Общее количество видов для зон (по табл. 12) & Значение $\varphi_{\text {эмп. }}$ Значение $\mathrm{p}$ \\
\hline $1-2$ & Asteraceae & $\left(\sum_{2}\right)$ & 0,472 & 0,3183 \\
\hline $1-3$ & Asteraceae & $\left(\sum_{2}\right)$ & 0,273 & 0,604 \\
\hline $2-3$ & Asteraceae & $\left(\sum_{2}\right)$ & 0,4207 & 0,2 \\
\hline $1-2$ & Poaceae & $\left(\sum_{2}\right)$ & 0,0587 & 1,566 \\
\hline $1-3$ & Poaceae & $\left(\sum_{2}\right)$ & $\mathbf{1 , 9 2}$ & $\mathbf{0 , 0 2 7 4}$ \\
\hline $2-3$ & Poaceae & $\left(\sum_{2}\right)$ & 0,2951 & 0,539 \\
\hline $1-2$ & Brassicaceae & $\left(\sum_{2}\right)$ & 0,0721 & 1,461 \\
\hline $1-3$ & Brassicaceae & $\left(\sum_{2}\right)$ & $\mathbf{2 , 0 5 1}$ & $\mathbf{0 , 0 2 0 1}$ \\
\hline $2-3$ & Brassicaceae & $\left(\sum_{2}\right)$ & 0,313 & 0,487 \\
\hline $1-2$ & Fabaceae & $\left(\sum_{2}\right)$ & 0,93 & 0,1763 \\
\hline $1-3$ & Fabaceae & $\left(\sum_{2}\right)$ & 0,956 & 0,1696 \\
\hline $2-3$ & Fabaceae & $\left(\sum_{2}\right)$ & 0,4858 & 0,036 \\
\hline $1-2$ & Rosaceae & $\left(\sum_{2}\right)$ & $\mathbf{1 , 8 4}$ & $\mathbf{0 , 0 3 2 9}$ \\
\hline $1-3$ & Rosaceae & $\left(\sum_{2}\right)$ & 2,318 & 0,0102 \\
\hline $2-3$ & Rosaceae & $\left(\sum_{2}\right)$ & 0,726 & 0,2338 \\
\hline $1-2$ & Lamiaceae & $\left(\sum_{2}\right)$ & 0,42 & 0,3372 \\
\hline $1-3$ & Lamiaceae & $\left(\sum_{2}\right)$ & 0,064 & 0,4747 \\
\hline $2-3$ & Lamiaceae & $\left(\sum_{2}\right)$ & 0,2907 & 0,551 \\
\hline $1-2$ & Apiaceae & $\left(\sum_{2}\right)$ & 0,257 & 0,3987 \\
\hline $1-3$ & Apiaceae & $\left(\sum_{2}\right)$ & 0,108 & 0,4571 \\
\hline $2-3$ & Apiaceae & 0,231 & 0,4086 \\
\hline
\end{tabular}

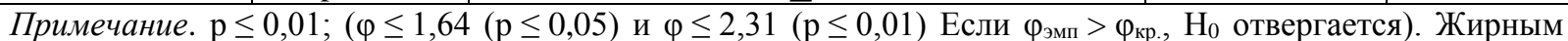
шрифтом выделены статистически значимые результаты.

Согласно результатам сравнения функциональных зон железнодорожного полотна по распределению особей ведущих семейств, большинство из них одинаково заселяет зоны (табл. 14). Обнаруженные различия в распределении семейства Роасеае в 1-3 зонах, Brassicaceae 1-3 зонах и Rosaceae в 1-2 зонах не влияют на общие тенденции формирования флоры (результаты Н-критерия). В результате чего можно констатировать незначительность биологических особенностей или «преимуществ» основных семейств в расселении по территориям, прилегающим к железнодорожному полотну.

\section{Выводы}

По результатам проведенных исследований можно сделать следующие выводы:

1. В пределах полосы отвода железных дорог наблюдаются значительные различия в степенях угнетения растительных организмов в зависимости от функциональной зоны. Вблизи полотна (0-2 м) наблюдается высокая степень угнетения, в зоне откосов полотна (2-4 м) наблюдается средняя, а в зоне, прилегающей к полотну (4-10 м), наблюдается средняя и низкая степень угнетения.

2. Распределение особей аборигенных и чужеродных видов не имеет значимых различий в пределах 1 и 2 функциональных зон (0-4 м от полотна). В пределах 3 зоны аборигенные виды преобладают над чужеродными, что может говорить о возрастающей роли прилегающих фитоценозов и уменьшении антропогенного воздействия на растительные организмы.

3. Распределение особей аборигенных и чужеродных видов между функциональными зонами 1-й (0-2 м) и 3-й (4-10 м) не имеет значимых различий. В пределах 2-й (2-4 м) и 3-й (4-10 м) зон количество аборигенных и чужеродных видов значительно отличается.

4. На долю первых 7 семейств флористического спектра приходится $62 \%$ от общего количества видов.

5. В сложении флоры железных дорог между аборигенным и чужеродным компонентами не зафиксировано значимых различий. Значимые различия зафиксированы на уровне сложения семейств.

6. В распределении особей ведущих семейств в пределах функциональных зон не обнаружено значимых различий, что указывает на незначительность биологических особенностей семейств при заселении функциональных зон железнодорожного полотна.

\section{Список литературы:}

1. Агеева А.М., Силаева Т.Б. Материалы к адвентивной флоре Республики Мордовия (на примере 
Торбеевского района) // Российский научный мир. 2014. № 2 (4). С. 91-103.

2. Березуцкий М.А. Антропогенная трансформация флоры // Ботанический журнал. 1999. Т. 84, № 6. C. $8-19$.

3. Сенатор С.А., Тохтарь В.К., Курской А.Ю. Материалы к флоре железных дорог Белгородской области // Вестник Удмуртского университета. Серия «Биология. Науки о Земле». 2016. Т. 26, № 4. С. 50-59.

4. Литвинов Д.И. О южных заносных растениях на северных станциях Мурманской железной дороги // Изв. АН СССР. VI сер. Т. 20. Л., 1926. С. 59-66.

5. Brandes D. Flora und Vegetation der Bahnhöfe Mitteleuropas // Phytocoenologia. 1983. Vol. 11. S. 31115.

6. Борисова Е.А. Инвазии древесных растений в природные сообщества Верхневолжского региона // Российский журнал биологических инвазий. Т.9, № 1. 2016. C. 24-30.

7. Galera H. et al. Encroachment of forest species into operating and abandoned railway areas in north- eastern Poland // Plant Biosystems. 2011. Vol. 145. P. 23-36.

8. Gańko K. Pozatransportowe funkcje terenów kolejowych // Teka Kom. Arch. Urb. Stud. Krajobr. OL PAN, 2005. S. 216-225.

9. Junghans T. Zur Flora der Hauptbahnhöfe von Mannheim und Heidelberg (Baden-Württemberg) // Braunschweiger Geobotanische Arbeiten. T. 9. 2008. S. 9.

10. Третьякова А.С. Роль железнодорожных магистралей в формировании синантропной флоры Среднего Урала // Экология. 2010. № 2. С. 102-107.

11. Dřevojan P. Vedoucí B., Roleček M. Xerotermní flóra a vegetace zářezů železniční trati Veselí nad Moravou-Vrbovce // Masarykova univerzita Přírodovědecká fakulta Ústav botaniky a zoologie. Brno, 2010.

12. Толмачёв А.И. Методы сравнительной флористики и проблемы флорогенеза. Новосибирск: Наука, 1986. $197 \mathrm{c}$.

13. Маевский П.Ф. Флора средней полосы европейской части России. Изд. 10-е. М.: Т-во науч. изданий КМК, 2006. 600 с.

\section{ECOLOGICAL AND BOTANICAL FEATURES OF THE RAILROADS FLORA OF THE MIDDLE VOLGA REGION}

(C) 2018

Nikitin Nikolay Alexandrovich, postgraduate student of Chair of Biology, Ecology and Methods of Teaching Samara State University of Social Sciences and Education (Samara, Russian Federation)

Abstract. The paper summarizes the study of ecological characteristics of the Railways flora in the Middle Volga Region. The author comes to the conclusion that in most cases there aren't any significant differences between aboriginal and alien species of the Railways flora, as well as their settlement of functional zones. The most significant differences have been recorded between aboriginal and alien species in the addition of families, which in turn does not have a decisive role in their addition to the flora as a whole. The author thinks that ecological features of the territory of individual growth are more important than biological features of species and families in the formation of the Railways flora. The developed «scale of oppression» allowed to determine characteristics of a particular individual. In the course of the research the dependence between the degree of oppression of plant organisms and the distance to the railroad tracks was established. The author found no significant differences in reactogenicity between the indigenous and alien species at active human impact on the Railways - both groups showed similar trends of oppression.

Keywords: railways flora; environmental conditions; anthropogenic impact; rail transport; inhibition of activity of individuals; taxonomic structure of flora; anthropogenic areas; transformation of flora; alien species; native species.

УДК 581.5; 581.526.5

Статья поступила в редакцию 05.01.2018

\section{АДАПТИВНЫЕ МЕХАНИЗМЫ ПРОРАСТАНИЯ СЕМЯН КСЕРОФИТНЫХ ЗЛАКОВ ВОСТОЧНОГО ЗАБАЙКАЛЬЯ}

(C) 2018

Пляскина Ирина Николаевна, старший лаборант кафедры биологии

Бондаревич Евгений Александрович, кандидат биологических наук, доцент кафедры химии и биохимии Коцюржинская Наталья Николаевна, кандидат биологических наук, доцент, заведующий кафедрой химии и биохимии

Читинская государственная медицинская академия (2. Чита, Российская Федерация)

Борискин Игорь Анатольевич, кандидат биологических наук, директор

Забайкальский аграрный институт - филиал Иркутского государственного аграрного университета имени А.А. Ежевского (г. Чита, Российская Федерация)

Аннотация. В статье представлены результаты изучения механизмов адаптации дикорастущих злаков Восточного Забайкалья на ранних этапах онтогенеза к условиям среды. Определена всхожесть семян трех видов ксерофитных злаков (Agropyron cristatum (L.) Beauv, Stipa krylovii Roshev, Tripogon chinensis (Franch.) Hack.). Отмечены различия в темпах прорастания зерновок этих злаков в зависимости от отношения к дефициту влаги. Более мезофильный вид (A. cristatum) имел самые высокие показатели всхожести. Большой вклад в обеспечение процесса прорастания вносят запасные питательные вещества, в частности белки. С общим количеством белка связана скорость прорастания. Семена, имеющие больше белка, прорастают быстрее, что может быть связано с появлением осмотически активных веществ в результате гидролиза, позволяющих эффективно использовать почвенную влагу. Семена одного вида злака, собранные в различных популяциях, могут от- 